\title{
Growth of Foreign Direct Investment in Indian Textile Sector
}

\author{
T. Selvakumar, A. Gunasekaran, G. Vinayagamoorthi
}

\begin{abstract}
Apart from being a critical driver of economic growth, foreign direct investment (FDI) is a major source of non-debt financial resource for the economic development of India. Foreign companies invest in India to take advantage of relatively lower wages, special investment privileges such as tax exemptions, etc. For a country where foreign investments are being made, it also means achieving technical know-how and generating employment. The Indian government's favorable policy regime and robust business environment have ensured that foreign capital keeps flowing into the country. The government has taken many initiatives in recent years such as relaxing FDI norms across sectors such as defence, PSU oil refineries, telecom, power exchanges, and stock exchanges, among others. The proposed paper deals with the structure and growth in FDI in Indian Textiles sector during the post reforms periods in India.
\end{abstract}

Keywords : FDI, FPI, Textiles, Garments, Inflow, Ministry of Textiles.

\section{INTRODUCTION}

Capital formation through Foreign Direct Investment plays an important role in the development of an industry. In the absence of enough domestic saving, external capital plays a vital role in providing the much needed resources for adequate capital formation in the country. Foreign Capital plays a significant role even when the country has sufficient domestic capital formation. This process of industrial development or production process requires not only capital but also some essential imported raw materials. Sometimes, sophisticated technology or technical know - how, determines the productivity of capital, which may not be available within the country. Imported raw material, advanced technology, technology, improved machinery, and technical know - how can be brought in, only by way of paying Foreign exchange for such purchases. Development in export may not be sufficient to meet out the requirements of Foreign exchange of the country. The requirements for foreign exchange gap and requirements of resources, technical know - how gap can be filled up only with the help of foreign capital.

The international financial market is also affected by the Foreign Direct Investment flows. The Foreign Direct Investment has emerged as the most important channel of external resources transfer to developing countries like India in the

Revised Manuscript Received on September 25, 2019

Dr. T.Selvakumar Assistant Professor,PG and Research Department of Economics, The American College (Autonomous) Madurai-625002, corresponding author

Dr. A.Gunasekaran Teaching Assistant, Department of Commerce, Madurai Kamaraj University College, Madurai, Tamilnadu

Dr. G.Vinayagamoorthi, Assistant Professor, Department of Commerce, 1990s. The Foreign Direct Investment had also acted as an agent of integration of economic activities across the countries in the 1990s. The Foreign Direct Investment inflows are expected to be less volatile and non - debt creating. They are also expected to be accompanied by a number of other assets that are valuable for development, such as sometimes even market access among others. Perhaps the most prominent face of globalization is the rapid integration of production and financial markets over the last decade; that is, trade and investment are the prime driving forces behind globalization. Hence, the changes occur in practically all countries in respect of the role of the state as economic regulator and owner have been observed. Expansion of the consumption demand component of Gross Domestic Product was surpassed by investment growth in the Asian region for the sixth consecutive year. This attributed to the positive outlook of investors and expectations of continued high rates of growth. ${ }^{1}$ Privatization, Liberalization, and Deregulation are the driving forces of economic development in the last decade particularly for the globalization process. Private ownership, entrepreneurship and open door economy are the key important factors in most economies. Due to Liquefied Petroleum Gas (LPG) process the Government of India has started inviting Foreign Direct Investment in the development of Indian industries. "Liberalization of Foreign Direct Investment policy is expected to attract large Foreign Direct Investment inflows in the development of infrastructure in manufacturing, and in projects having potential for creating employment opportunities".

The last two decades of the $20^{\text {th }}$ century witnessed a marked change in the attitude of the most developing countries towards foreign capital, accompanied by a dramatic worldwide increase in Foreign Direct Investment. As against a highly suspicious attitude of these countries towards inward Foreign Direct Investment in the past, most countries including their development effort compete with each other to attract it. In the last decade of $20^{\text {th }}$ century most of the countries changed their political and economic system in such a way to attract more and more Foreign Direct Investment. Many countries abandoned socialism in its various forms and embraced the

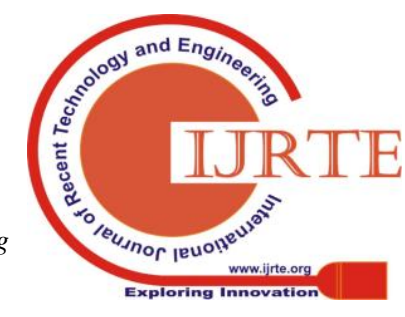


market economy. In many of the Eastern European Countries, mass privatization has taken place mainly with the investment from abroad. Even many of the Asian countries including China, South Korea, Singapore, Thailand and Malaysia are largely attributable to a high level of Foreign Investment and export promotion. India is one of the most transparent and a liberal Foreign Direct Investment regime among the developing countries with strong economic fundamentals, but still suffers from weaknesses and constraints, in terms of policy and regulatory frame work.

Private Foreign Investment in developing and less developed countries is vast, complicated and controversial and also much speculative over the years. Hence, it has received less attention in terms of data collection and analysis than any other form of economic development. The recent acceleration flow of the Foreign Direct Investment has received an interest in considering the Trans National Corporation (TNCs) as the engine of growth of developing countries particularly in India. It can generate employment in the host countries, in addition to supplementing domestic savings and help to meet the huge demand for investment. The Foreign Direct Investment can also bring foreign currencies into the host countries by stimulating export of goods and services. Expectations of significant future domestic demand, especially in countries with large population such as India, can result in Foreign Direct Investment from foreign companies establishing large population bases in the domestic market. Such Foreign Direct Investment will expand product variety and consumer choices and promote technology transfers and knowledge spillovers through forward and backward linkages in the host economies. In order to attract more Foreign Direct Investment into India, the Government of India is liberalizing its economic policy continuously. In South Asia, India plays a dominant role in attracting the Foreign Direct Investment, thus it could achieve 8 per cent plus economic growth in the recent years. Though, the government offers more benefits to foreign investors, the inflows of the Foreign Direct Investment again are very small compared to China. In this content, the present study analyses the determinants of the Foreign Direct Investment impact on Indian economy in general and industrial development in particular.

Foreign Direct Investment (FDI) is considered to be the lifeblood for economic development as far as the developing nations are concerned. Since the liberalization of the Indian economy inflows of foreign direct investment has greatly increased. As far as forting direct investment is concerned, its flow in India is very small as compared not only to China but also to India's potential. Economic Survey for 2005-06 points out that India has potential to absorb $\$ 150$ billion

Foreign Direct Investment in the infrastructure sectors alone by 2010.Most of the Foreign Direct Investment inflows come from a few countries. Between 1991 and 2005, investments of 10 countries accounted for 71 percent of Foreign Direct Investment, the main investor countries being the USA, the Netherlands, Japan, and the United Kingdom. With regard to Foreign Direct Investment, U.S. is one of the largest foreign direct investors in India. India is becoming an attractive location for global business on account to its buoyant economy, its increasing consumption market, and its needs in infrastructure in the engineering sector. Opening and Foreign Direct Investment have really created new opportunities for India's development and boosted the performances of local firms as well as the globalization of some of them. Such a trend has undeniably raised Indian's stature among developing countries.

A foreign direct investment (FDI) inflow in India is a defining feature of free market, liberalization and globalization. The important aspect is that how and through what channels impact of Foreign Direct Investment inflows affects the performance of companies in developing countries. One major channel through which inflows of foreign capital, of foreign direct investment (FDI) in particular, affect labour markets in developing countries is economic growth. If capital inflows enable the recipient developing countries to increase the investment rate beyond what they could sustain with their domestic savings, they should achieve accelerated economic growth with favorable consequences for employment, wages and labour productivity. Emerging markets possess a lot of potential for foreign direct investment (FDI). Foreign Direct Investment in India is on the increase but the country has not experienced a rapid growth of Foreign Direct Investment inflow. Theories of Foreign Direct Investment suggest that firm size, profitability, trade, interest rates, economy and inflation yield significant influence in attracting Foreign Direct Investment.

\section{TYPES OF FOREIGN INVESTMENT}

Foreign Investment can be classified as,

\section{a)External assistance or official sources:}

Both concessional and non - concessional flows from official sources like official Development funds through bilateral agreement from International Monetary Fund, World Bank, Asian Development Bank and the like which includes Grants, concessional Loan and Non - concessional loan flows, sometimes it may be provided by developed countries to developing country with the objectives of assisting economic development.

b) Private capital flows or Non official sources: $\begin{aligned} & \text { These flows of } \\ & \text { investment from } \\ & \text { Multinational }\end{aligned}$ 
Corporations (FDI), Foreign Institutional Investors

(FII), the Non - Resident investment, external bank loans, and other credits like buyers credit, Suppliers credit, Floating bonds and fixed bonds

Table 1.1Foreign Direct Investment flow by Region \& Economy 2008 - 2010 (US \$ million)

FDI Inflow

\begin{tabular}{|l|c|c|c|c|c|c|}
\hline Region/Economy & 2008 & 2009 & 2010 & 2008 & 2009 & 2010 \\
\hline World & $7,58,697$ & $14,11,018$ & $18,33,324$ & $8,80,808$ & $13,23,150$ & $19,96,514$ \\
\hline Developed Economy & $6,11,283$ & $9,40,861$ & $12,47,635$ & $7,48,885$ & $10,87,186$ & $16,92,141$ \\
\hline $\begin{array}{l}\text { Developing } \\
\text { Economy }\end{array}$ & $3,16,440$ & $4,12,990$ & $4,99,747$ & $1,17,579$ & $2,12,258$ & $2,53,145$ \\
\hline Asia & $2,10,028$ & $2,72,890$ & $3,19,333$ & 79,412 & $1,41,105$ & $1,94,663$ \\
\hline India & 7,606 & 19,662 & 22,950 & 2,978 & 12,842 & 13,649 \\
\hline $\begin{array}{l}\text { \% in Developing } \\
\text { Economy }\end{array}$ & 2.40 & 4.76 & 4.59 & 2.53 & 6.05 & 5.39 \\
\hline
\end{tabular}

Source: World Investment Report - 2010

It's clear from table 1.1, that the inflow of the Foreign Direct Investment to India is merely 2.40 percentage of the total Foreign Direct Investment inflow to developing economy in the year 2008 and it increased to 4.59 per cent in 2010. The outflow of the Foreign Direct Investment from India in the year 2008 is US \$2,928 (2.53 per cent) and it increased to 6.5 per cent in 2009 and decreased to 5.39. But the inflow of the Foreign Direct Investment to Asia amounted to US \$2, 10,028 US $\$ 79,412$ million, which is less than the inflow to the Asian country. This trend has increased to an inflow of US $\$ 3,19,333$ million in 2010 and on outflow of US $\$ 1,94,663$ million.

Table 1.2 -Year Wise Foreign Direct Investment (FDI) Approvals and Inflows (from August 2000 to February 2010)

\begin{tabular}{|c|c|c|c|c|c|c|}
\hline \multirow[t]{2}{*}{ Sino } & \multirow[t]{2}{*}{$\begin{array}{l}\text { Year (January - } \\
\text { December) }\end{array}$} & \multicolumn{2}{|c|}{ Amount in Rupees core } & \multicolumn{2}{|c|}{$\begin{array}{l}\text { Amount in US \$ in } \\
\text { million }\end{array}$} & \multirow{2}{*}{$\begin{array}{l}\% \text { age of } \\
\text { realization rate } \\
\text { inflow } \\
\text { Approval (in terms } \\
\text { of Rupees) }\end{array}$} \\
\hline & & $\begin{array}{l}\text { FDI } \\
\text { Approval }\end{array}$ & $\begin{array}{l}\text { FDI } \\
\text { inflows }\end{array}$ & $\begin{array}{l}\text { FDI } \\
\text { Approvals }\end{array}$ & $\begin{array}{l}\text { FDI } \\
\text { inflows }\end{array}$ & \\
\hline 1. & 2000 & 27590 & 13269 & 6985 & 3359 & 48.09 \\
\hline 2. & 2001 & 25140 & 10167 & 5986 & 2421 & 40.44 \\
\hline 3. & 2002 & 17237 & 12354 & 4009 & 2873 & 71.67 \\
\hline 4. & 2003 & 20940 & 16778 & 4653 & 3728 & 80.12 \\
\hline 5. & 2004 & 11058 & 18196 & 2304 & 3791 & 164.55 \\
\hline 6. & 2005 & 5417 & 11617 & 1178 & 2526 & 214.45 \\
\hline 7. & 2006 & 8741 & 17266 & 1900 & 3755 & 197.52 \\
\hline 8. & 2007 & 7900 & 19299 & 1775 & 4360 & 244.29 \\
\hline 9. & 2008 & 23003 & 50357 & 5111 & 11122 & 218.91 \\
\hline 10. & 2009 & 19911 & 79736 & 4773 & 9156 & 400.46 \\
\hline & 2010 & 11884 & 89233 & 2941 & 21963 & 750.86 \\
\hline & Total & 313117 & 372518 & 81890 & 89292 & 118.9709 \\
\hline
\end{tabular}

Source: Ministry of Commerce \& Industry, Department of Industrial Policy and Promotion.

In table 1.2 the percentage of realization of the Foreign Direct Investment in respect to the approval was less, compared to later periods. The realization rate was very less in 1995 with the rate of merely $21 \%$. This is due prior to 2003 , the Foreign Direct Investment in India was very narrow which includes only equity part of the Foreign Direct Investment and does not include other forms like reinvested earnings by foreign companies, acquisition of shares and the like. After 2003, India accepted the International Monetary Fund road map to calculate the Foreign Direct Investment with wide coverage. Due to that the amount of Foreign Direct Investment inflow data shows very positive and high inflow into India during the later period and achieved Rs.89, 233 cores in 2010. This chapter shows the approved and actual inflow of the Foreign Direct Investment in India.

\section{INDUSTRIAL DEVELOPMENT IN INDIA}

Industrial development in India divided into two phases like during the British period and after independence. Industrial developments have been accelerated in India after independence by introducing five year plan with specific objectives or sectors in each plan periods. The industrial growth was stagnant before introducing

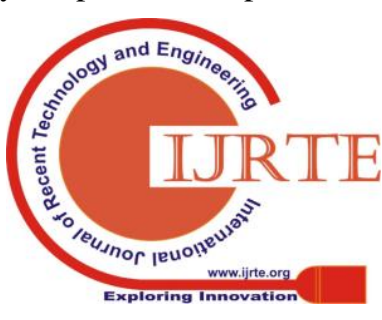


globalization, later there were dramatic growths in various sectors including public sector industry.

Table.1.3.Annual Industrial Growth Rates during various plan periods

\begin{tabular}{|c|c|c|c|}
\hline S.NO & Plan period & Year & $\begin{array}{c}\text { Annual Average } \\
\text { Growth rate during } \\
\text { plan period }(\%)\end{array}$ \\
\hline 1. & Third plan & $1961-66$ & 8.2 \\
\hline 2. & Annual plan & $1966-67$ & 0.6 \\
\hline 3. & Annual plan & $1967-68$ & 1.2 \\
\hline 4. & Annual plan & $1968-69$ & 6.7 \\
\hline 5. & Fourth plan & $1969-74$ & 4.4 \\
\hline 6. & Fifth plan & $1974-78$ & 5.9 \\
\hline 7. & Annual plan & $1978-79$ & 7.6 \\
\hline 8. & Annual plan & $1979-80$ & -1.6 \\
\hline 9. & Sixth plan & $1980-85$ & 5.9 \\
\hline 10. & Seventh plan & $1985-1990$ & 8.5 \\
\hline 11. & Annual plan & $1990-1991$ & 8.3 \\
\hline 12. & Annual plan & $1991-92$ & 0.6 \\
\hline 13. & Eighth plan & $1992-1997$ & 7.3 \\
\hline 14. & Ninth plan & $1997-2002$ & 5.0 \\
\hline 15. & Tenth plan & $2002-2007$ & 8.1 \\
\hline
\end{tabular}

Source: various issues of Economic Survey report from 1961 - 62 to 2006 - 07.

Table 2.10, shows the industrial growth rate during various plan periods. India achieved a high growth rate during seventh plan period. The interesting point is that India did not allow FDI during this period, and in spite of this it could achieve $8.5 \%$ of industrial growth rate. There was a negative growth rate $(1.6 \%$ achieved during the annual plan period of $1979-$ 80. Industrial performance during the tenth plan period reached $8.1 \%$ growth rate. This is more or less better performance among the Asia countries.

\section{FDI IN TEXTILES \& GARMENTS}

India's textiles sector is one of the oldest industries in Indian economy dating back several centuries. India's overall textile exports during FY 2017-18 stood at USD \$39.2 bn in FY18 and is expected to increase to USD $\$ 82$ bn by 2021 from USD $\$ 31.65$ bn in FY19.

Abundant availability of raw materials such as cotton, wool, silk, jute and manmade fibres has led India to be one of the world's largest producers of textiles and garments. The country has become an attractive destination for FDI in the Indian textile industry thanks to foreign direct investment policy in textiles. The Indian domestic textile and apparel industry contributes $2 \%$ to India's GDP, $14 \%$ of industrial production, $27 \%$ of the country's foreign exchange inflows and constitutes $13 \%$ of country's export earnings. Exports in the Textiles \& garments industry are expected to reach $\$ 300$ bn by 2024 .

\section{FOREIGN DIRECT INVESTMENT POLICY IN TEXTILES}

Indian textile and apparel industry is one of the largest in the world with US\$ 19 billion of export and US\$ 30 billion of domestic textile and apparel during 2006-07 (P). The industry has, over the years, contributed significantly to national output, employment and exports. At present, industry accounts for about $14 \%$ of our total industrial production and contributes to nearly $15 \%$ of total exports. It provides direct employment to about 35 million people and another 56 million are engaged in allied activities. The textile export has registered a growth of 10 percent to 19.24 billion during 2006-07 (P) from US\$ 17.85 billion during 2005-06. The Industry has a potential to reach a size of US\$ 85 billion by 2010. With its consistent growth performance and abundant cheap skilled manpower, there are enormous opportunities both for domestic and foreign investors to make investments in textile sector in India.

India has most liberal and transparent policies in Foreign Direct Investment (FDI) amongst emerging countries. India is a promising destination for FDI in the textile sector. 100\% FDI is allowed in the textile sector under the automatic route. FDI in sectors to the extent permitted under automatic route does not require any prior approval either by the Government of India or Reserve Bank of India (RBI). The investors are only required to notify the Regional Office concerned of RBI within 30 days of receipt of inword remittance.Ministry of Textiles has set up FDI Cell to attract FDI in the textile sector in the country. 


\section{FDI IN TEXTILE SECTOR}

FDI in textile sector can be into -

Manufacturing - $100 \%$ FDI permitted under automatic route, Manufacturer is permitted to sale itsproducts manufactured in India through wholesale and/ or retail, including through e-commerce without government approval Single brand retail trading - $100 \%$ - Automatic up to $49 \%$.

Government route beyond $49 \%$ subject to the prescribed conditions. Multi-brand retail trading Automatic upto $51 \%$, beyond $51 \%$ Government route subject to the prescribed conditions Application seeking permission of the Government for FDI exceeding the prescribed \% in a company which proposes to undertake single/multi brand retail trading in India would be made to the Secretariat for Industrial Assistance (SIA) in the Department of Industrial Policy \& Promotion.

\section{RECENT INVESTMENTS IN TEXTILE SECTOR}

The industry (including dyed and printed) attracted FDI worth US\$ 1.85 billion during April 2000 to March 2016. Some of the major investments in the Indian textiles industry are:

Trident Group - entered into a partnership with French firm Lagardere Active Group, to launch a premium range of home textiles under the renowned French lifestyle brand Elle Décor in India. • Raymond Group - signed a MoU with Maharashtra government for setting up a textile manufacturing plant with an investment of Rs1,400 crore (US\$ 207.53 million) in Maharashtra's Amravati district.

Reliance Industries Ltd (RIL) plans to enter into a joint venture (JV) with China-based Shandong Ruyi Science and Technology Group Co. The JV will leverage RIL's existing textile business and distribution network in India and Ruyi's state-of-the-art technology and its global reach.

Giving Indian sarees a 'green' touch, Dupont has joined hands with RIL and Vipul Sarees for use of its renewable fibre product Sorona to make an 'environment-friendly' version of this ethnic ladies wear.

Grasim Industries has invested Rs 100 crore (US\$ 14.82 million) to develop its first fabric brand, 'Liva', which it will distribute through 1,000 outlets as part of a plan to stay in sync with changing consumer behaviour.
Snap deal has partnered with India Post to jointly work on bringing thousands of weavers and artisans from Varanasi through its website.

Wels pun India Ltd (WIL), part of the Welspun Group has unveiled its new spinning facility at Anjar, Gujarat - the largest under one roof in India. The expansion project reflects the ethos of the Government of Gujarat's recent 'Farm-Factory-Fabric-Fashion-Foreign' Textile Policy, which is aimed at strengthening the entire textile value-chain.

American casual fashion retailer Aéropostale, Inc. has inked a licensing agreement with Arvind Lifestyle Brands Ltd to open standalone stores in the country. Aéropostale will open 30 stores and 25 shop-in-shop locations over the next three years.

\section{CONCLUSION}

The research study found that the Foreign Direct Investment plays a significant role in the process of economic development of India. The Foreign Direct Investment is essential for the development to Indian economy. Indian economy has grown substantially around $8.56 \%$ in the year 2009 - 2010. But often the Foreign Direct Investment creates confusions like domestic savings rate, political pressures, production of basic goods and services. The role of the foreign investment during the pre-independence period was to exploit the natural resources and suppress the Indian traditional business. As the colonial master, Britain with high business interests in India was the key driver of trade policies in India during this period.

The Foreign Direct Investment policies should be framed by considering the industrial development specifically and economic development in general. The Government should formulate the policy in order to regulate the multinational companies in India, but not interfere and control their business activities and their business strategies. Further research can be undertaken in the same discipline with extended periods. This study contributed significant insight in the field of Foreign Direct Investment and industrial performance in India.

\section{REFERENCES}

[1] Christine Heumesser ,Erwin Schmid- Trends in foreign direct investment in the agricultural sector of developing and transition countries: a review- University of Natural Resources and Applied Life Sciences, Vienna Department of Economic and Social Science- July 2012

[2] Monism Goliath- Assistant Professor, Department of Agricultural and Resource Economics, Oregon State University. Research assistance from Kweiyang Chen is acknowledged. Materials from an earlier study, "Effects of FDI in Developing Countries: The Case of Food and Agriculture," by C.H. Bulling and M. Goliath served as a basis for some of the following sections

[3] www.fao.org

[4] www.unctad.org 


\section{Growth of Foreign Direct Investment in Indian Textile Sector}

[5] Trends and impacts of foreign investment in developing country agriculture-FAO-2013.

[6] Ping Lin and Kamala Saggy, "Incentives for Foreign Direct Investment under Imitation" Canadian Journal of Economics, Vol.32, No.5, November 1999, p.1276.

[7] Bornschier. V., and C. Chase - Dunn, 1985 "Transnational Corporations and underderdevelopment", Newyork Pracger.

[8] Das S (1987), "Externalities and Technology Transfer through Multinational Corporation: A Theoretical Analysis", Journal of international economics, 123 pp. 188 - 206.

[9] Froot, Kenneth A and Stein Jeremy C. (1991) "Exchange Rate and Foreign Direct Investment: And imperfect capital market Aapproach " Quarterly Journal of Economics 106 (4) , 1991, pp.1191 - 1217.

[10] Wheeler, D. AND Mody, A. (192), "International Investment Location decision: The case of US firms", Journal of International Economics, Vol.33, No.1/2, pp.57 - 76

[11] Campa Jose M (1993) Entry by Foreign firm in the US under exchange rate uncertainity", Review of Economics and Statistics, 75(4): pp. 622 $-624$.

[12] Tsai, Pan - Long (1994), "Determinants of Foreign Direct Investment and its Impact on Economic Growth", Journal of Economic Development, 19, pp. $137-163$.

[13] http://texmin.nic.in/fdi-cell

[14] https://www.fdi.finance/sectors/textiles-and-garments

[15] http://www.textileassociationindia.org 